Çukurova Üniversitesi Mühendislik Mimarlık Fakültesi Dergisi, 33(4), ss. 165-174, Aralık 2018

Çukurova University Journal of the Faculty of Engineering and Architecture, 33(4), pp. 165-174, December 2018

\title{
Soya ve Pamuk Lifi İçeren Dokusuz Yüzey Kumaşların Hijyen Tekstili Performansının Deneysel İncelenmesi
}

\author{
Dilek EKİNCí1 ${ }^{1}$ Emel Ceyhun SABIR*1 \\ ${ }^{1}$ Çukurova Üniversitesi, Mühendislik Fakültesi, Tekstil Mühendisliği Bölümü, Adana
}

$\ddot{O} z$

Geliş tarihi: 09.04.2018 Kabul tarihi: 25.12.2018

Bu çalışmada, soya ve pamuk lifleri içeren sekiz farklı dokusuz yüzey elde edilmiştir. Kumaşlar hijyen tekstilinde kullanılan bebek/hasta bezinin ADL katmanında kullanılacak şekilde tasarlanmıştır. Numuneler, Air-Trough Bonding (Hava ile tülbent oluşturma) makinesinde üretilmiştir. Dokusuz yüzeylerde; taşıуıсı lif olarak soya ve pamuk, bağlayıcı lif olarak 6 denye kalınlığında ve $64 \mathrm{~mm}$ uzunluğunda iki bileşenli iç/dış formunda Polietilen)/Poliester ve iki bileşenli Polietilen/Modifiye edilmiş Poliester lifleri kullanılmıştır. Soya ve pamuk ayrı ayrı farklı oranlarda polietilen/poliester'le birlikte kullanılmıștır. Numunelere bebek/hasta bezleri için geçerli performans testleri uygulanmıştır. Soya lifi içeren numunelerin sslak halde daha mukavemetli olduğu görülmüștür. Çapraz yöndeki mukavemet sonuçlarında ise en iyi değerler; kuru ve sslak halde soya/polietilen/modifiye polyester numunelerinden elde edilmiş̧ir. Sıvı geçiş hızı, 1slatma ve kuruluk değerlerindeki en iyi sonucu Soya/polietilen/polyester numuneleri göstermiş̧ir Çalışma sonuçları, hijyen tekstilinde soya lifinin bebek/hasta bezinde üst yüzeyden emici yüzeye aktarımında performansının üst düzeyde olduğunu göstermiştir.

Anahtar Kelimeler: Soya, Dokusuz yüzey, Hijyen tekstili, Bebek bezi

\section{Experimental Investigation of Hygienic Textile Performance of Nonwoven Fabrics Containing Soybean and Cotton Fiber}

\begin{abstract}
In this study, eight different nonwoven surfaces containing soy and cotton fibers were. The fabrics are designed to be used in the ADL layer of the baby/patient cloth used in hygiene textiles. The samples are manufactured in Air-Trough Bonding machine. On nonwovens; Polyethylene/Polyester/Biaxially Polyethylene/Modified Polyester fibers in two component inner/outer form with 6 denier thickness and $64 \mathrm{~mm}$ length as binder fiber are used as carrier fiber. The performance tests for the baby/patient cloths were applied to the samples. Samples containing soy fiber were found to be more durable in wet condition. The best values for strength results in the cross direction; dry and wet soybean/polyethylene/modified polyesters. The best result in liquid transit speed, soaking and dryness values showed soy/polyethylene/polyester samples. The study results showed that the performance of the soya fiber in the hygiene textile is superior in transferring from the upper surface to the absorbent surface in the baby/sick cloth.
\end{abstract}

Key Words: Soybean, Nonwoven fabric, Hygiene textile, Baby diaper

*Sorumlu yazar (Corresponding author): Emel Ceyhun SABIR, emelc@cu.edu.tr 


\section{GíRiș}

Soya lifi (SPF) rejenere protein esaslı bir liftir. İlk olarak 20. yy'ın ortalarında üretilmeye başlanmıştır. Fakat liflerin üretimi sırasında mukavemetin düşük olmasından dolayı karşılaşılan önemli zorluklar, lif üretiminin azalmasına neden olmuştur. Yün ve ipek gibi doğal protein lifleri iyi fiziksel özelliklere sahip olmalarına ve tekstil endüstrisinde yaygın bir șekilde kullanılmalarına rağmen, bu liflerin kullanımı ve işlenmesi oldukça pahalıdır. Fakat soya fasulyesinin ucuz ve bol olması bu life olan ilgiyi arttırmış yün ve kaşmir liflerini tamamlayacak veya onlarla rekabet edebilecek bir lif olarak görülmüştür. Ayrıca liflerin mukavemeti, lif üretiminde polivinilalkol (PVA) dahil edilmesi ile geliştirilmiştir. Günümüzde çevre dostu ve biyobozunur kaynaklardan üretilen liflere olan ilginin artması sonucu SPF'de tekrar gündeme gelerek artan bir hızla tekstil sektöründe kullanılmaya devam etmektedir. SPF kaşmir, yün, ipek, pamuk ve zein gibi diğer lifler ile karışım halinde kullanılmaktadır. Türkiye'de soya ekimi özellikle Akdeniz Bölgesi'nde yapılmaktadır [1].

Soya lifinin kimyasal yapısına bakıldığında asidik aminoasit miktarları yünün asidik aminoasit miktarlarından daha yüksektir ve lifin ağır basan aminoasidi glutamik asittir. Bununla birlikte, disülfit grupları boyunca çapraz bağlantıların azlığını gösteren, sülfür içeren sistin gibi aminoasit miktarları da yünden daha azdır. Soya lifinin baz ve asit dayanımları ipek ve yün liflerine benzemektedir. SPF'nin mantar dayanımı yün ve ipek lifleri ile benzer özellik gösterirken güve dayanımı ise yün, ipek ve pamuk liflerinden daha iyidir [2].

Soya lifi üretiminde kullanılan materyaller, ek ve yardımcı maddeler zehirli değildir. Yarı mamul soya lifi çoğu ilave maddenin yardımıyla geri kazandırılarak yeniden kullanılabildiğinden dolayı ekolojik bir liftir. Soya lifinin fiziksel özellikleri incelendiğinde ham rengi açık kahve-altın rengi tonlarından açı ten rengine kadar değişen çeşitli tonlarda olabilmektedir. SPF'nin kohezyon kuvveti oldukça düşük olduğundan lif çekimi sırasında kaydırmazlık maddesi kullanılması gerekmektedir. Soya lifine ait elastiki geri dönme oranı da $\% 55,4$ ölçülmüştür ve bu değer diğer kimyasal liflerin ortak değerinden (diğer kimyasal liflerde elastiki geri dönme oranı \%70-80) daha düşüktür. Soya lifinin, iyi derecede nem çekme ve hava geçirgenliği özelliklerine sahip olduğu fakat yaş mukavemetinin düşük olduğu belirtilmektedir. Soya lifinden üretilen kumaşlara uygulanacak boyama ve isıl işlemlerin $100{ }^{\circ} \mathrm{C}$ 'yi geçmemesi tercih edilmektedir. Soya lifinden üretilen tekstil yüzeyleri \%87'lik oldukça yüksek bir UKÖ (Uzak kızıl ötesi) ışını emme oranı göstermektedir. Zararlı ultraviyole ışınlarını emme yüzdesi \%99,7'ye kadar çıkabildiğinden dolayı ultraviyole 1şınlarından koruma özelliği vardır [2].

Literatürde soya lifi ile yapılan bir çalışmada; lif yapısı ve karışımı, alev ve UV dayanımı, mukavemet, boncuklanma davranışı, hava ve su buharı geçirgenliği, su emme, ve boyama özellikleri incelenmiştir. Soya fasulyesi elyafının klasik ve teknik tekstil ürünlerinin performans, konfor ve fonksiyonel gereksinimlerini karşılayabildiği belirtilmiştir. Soya lifinin performans özellikleri analiz edildiğinde, soya lifi ve onun çeşitli liflerle karışımıyla örülen kumaşların, pamuk ve bambu ile örülen kumaşlardan daha yüksek patlama mukavemetine ve daha iyi boncuklanma değerine sahip olduğu tespit edilmiştir. Soya lifinin; doğal liflerin iyi niteliklerinin birçoğuna ve ayrıca alev geciktirici ve anti-ultraviyole gibi sentetik liflerin bazı işlevsel özelliklerine de sahip olduğu belirtilmiştir [3].

Başka bir çalışmada, \%90/10 Pamuk/Seacell, \%90 Pamuk / \%10 Gümüş, \%100 Pamuk, \%100 Bambu ve $\% 100$ Soya iplikleri kullanılarak üretilen süprem örgü kumaşların ısıl konfor, nem yönetim kabiliyetleri ve tutum özellikleri incelenmiştir. Test sonuçları, soyadan üretilen kumaşların en iyi 1s1 direncine ve nem yönetim özelliklerine sahip olduğunu ortaya koymuştur [4].

Egzersiz sırasında maksimum termal-1slak rahatllğg sağlamak için farklı türdeki kumaşları giymek için yeni bir yöntemin uygulandığı bir çalışmada Pamuk, yün, liyosel, model, soya fasülyesi, bambu 
ve bunların harmanları gibi on türden higroskopik liflerden oluşan on tişörtün termal-1slak konforu, incelenmiştir. Deneysel sonuçlar, on çeşit tshirtün termal-1slak konforunun, egzersiz sirasında isı ve nem transferini etkileyen lif tiplerine bağlı olarak değiştiğini göstermektedir. Doğal higroskopik elyaf olan pamuk ve yünün diğerlerinden daha fazla nem çektiği ve daha fazla termal olduğu, rejenere selülozik lifler, bambu, soya ve model lifleri ile üretilen kumaşların egzersiz sırasında daha az termal ve nemli iken, model çok yapışkan ve bambu dokunuş için önemli bir soğukluğa sahip olduğu ve karışım kumaşlardan yapılan test k1yafetleri, orta derecede termal-1slak konfor sergilediği tespit edilmiştir [5].

Bir deneysel çalışmada \%100 Pamuk (P), \%50 Pamuk-\%50 Modal (PM), \%50 Pamuk-\%50 Viloft (PV), \%100 Modal (M), \%100 Viskon (VI), \%100 Bambu (B), \%50 Pamuk-\%50 Bambu (PB), $\% 100$ Seacell (SC) ve \%100 Soya(SO) olmak üzere 9 farklı iplikten örülen 9 grup çorabın konfor özellikleri incelenmiştir. Deney sonuçlarına göre soya lifinin; düşük nem kazanımı $(\% 5,36)$, düşük 1slanma oranı (\%24) ve düşük kılcal transfer değerlerine dolayısıyla az su sever bir yapıya sahip olduğu tespit edilmiştir. Çalışmada, soyalı çorapların su buharı transfer değerleri diğer liflere göre daha yüksek çıkmıştır. Sıvı transferi bakımından su itici lif gibi davrandığı, sıvıyı lif içine almayıp yüzeysel harekete olanak sağladığı bu yüzden yüksek bir su buharı transferine ve hızlı kurumaya imkan verdiği belirtilmiştir. Isı transferinin ise en düşük değerler soyalı çoraplarda görülmüştür. $\mathrm{Bu}$, 1sıyı iletmeyen ancak 1sıyı tutan bir yapıda olduğu belirtilmiştir. Soyalı çorapların fiziksel performansta yüksek mukavemete sahip olduğu ancak, boyutsal değişim bakımından diğer liflere göre en kötü değerler elde edilmiştir [6].

Başka bir araştırmada soya proteininin (SP) aşılanmasıyla modifiye edilen poliakrilonitril (PAN) lifleri üzerine yeni bir metot çalışılmıştır. Reaktan PAN-g-SP elyafi hidrolize edilmiş PAN elyafı kullanılmıştır. Sonuçlar SP'nin PAN elyafı üzerine aşılanmış olduğunu göstermiştir. PAN-gSP' nin aynı zamanda iyi bir nem çekme özelliği ve uygun mekanik özellikler sergilediği tespit edilmiştir[7].
Literatür incelendiğinde ülkemizde de tanınmaya başlanan soya lifinin sahip olduğu yumuşaklık, dökümlülük, parlaklık, yenilenebilirlik, biyobozunurluk gibi avantajlar yanında hammaddesi olan soya fasülyesinin kolay bulunabilmesi ve ucuz olması sayesinde gelecek vaadettiği görülmektedir.

Bu çalışmada, tüm toplumlar için bebek ve insan sağlığı açısından çok önemli bir ürün olan bebek bezi ve hasta bezi gibi hijyenik ped üretiminde kullanılmak üzere dokusuz yüzey üretilmiştir. Günümüzde, özellikle bebek bezlerinin tüketiminin oldukça fazla olması çevresel kaygıları da gündeme getirmektedir. "Bebek bezlerinin çok katmanlı yapıdan ve petrol kökenli maddelerden oluşması çevresel açıdan büyük tehdit oluşturmaktadır. Bebek bezlerinin oluşturduğu atık miktarının çok fazla oluşu, bebek bezleri üzerine yapılan çalışmaların önemini de ortaya koymaktadır. Yapılan çalışmada bu konu üzerine ülkemizde çalışmaların yeterli olmadığı görülmüştür. Sonuç olarak giderek artan atık sorununun çözümü için bebek bezinde kullanılan plastik tabakalar yerine doğada çözünen biyobozunur malzemeli bebek bezi üretimi teşvik edilmelidir" [8].

Medikal tekstilde hijyenik tekstil ürünleri oldukça fazla kullanılmaktadır. Medikal tekstil ürünleri, teknik disiplinler ve yaşam bilimleri arasında yer alan araştırma alanıdır (Şekil 1).

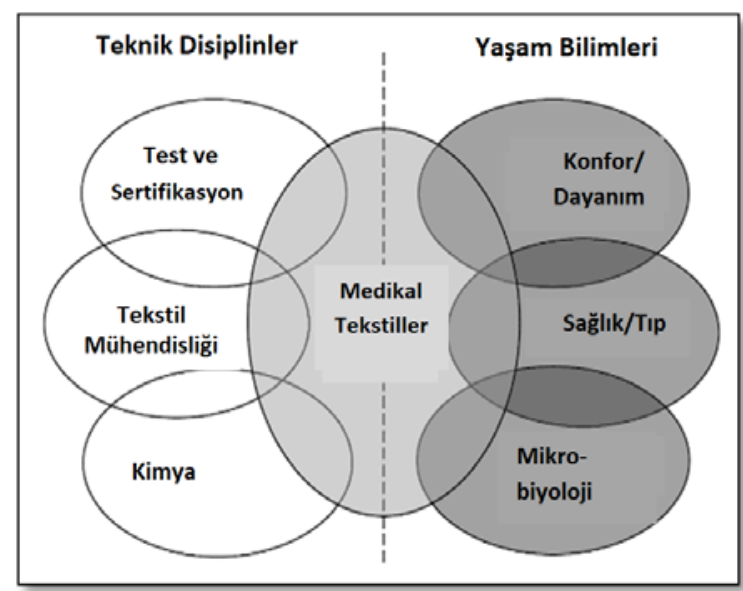

Şekil 1. Medikal tekstiller [9] 
Hijyenik tekstil ürünleri genellikle tek kullanımlık olup, bebek ve hasta bezleri en çok kullanılan ürünlerdir. Bu bezler; üst tabaka, emici tabaka ve alt tabaka şeklinde 3 ana katmanlı yapıdadır. Üst tabaka ile emici tabaka arasında dağıtıcı tabaka bulunur. Dağıtıcı tabaka (Acquisition-Distribution Layer - ADL), üst tabakadan sıviyı alır ve depolar (Şekil 2). ADL olarak tedarik edilen dokusuz tekstil yüzeyi, Air-Through Bonded Nonwoven tekniği ile çocuk bezi, hijyenik ped ve hasta bezi üreticilerine sıvının üst tabakadan emilimini ve alt katmanlara yayılımını artırarak bezlerin ve pedlerin tüm alanı boyunca fonksiyon göstermesini sağlar. Bu özel yapı, aynı zamanda sıvının tekrar yüzeye yürümesini engelleyici bir bariyer görevi üstlenir ve diğer bileşenler ile birlikte cildin kuru, temiz ve sağlıklı kalmasına yardımcı olur [10].

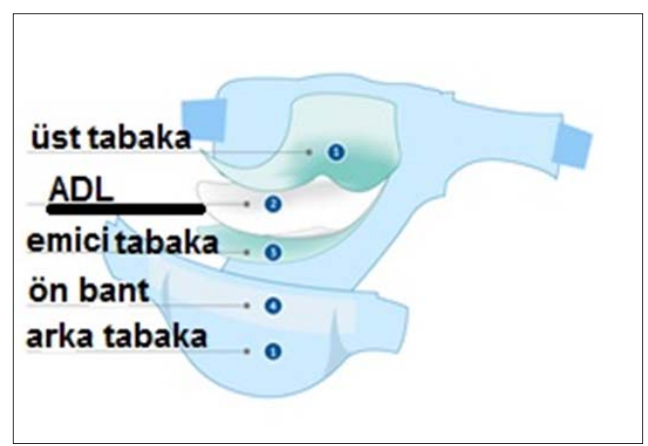

Şekil 2. Bebek bezinde ana katmanlar

Çalışma konusu olan dokusuz (nonwoven) yüzeyler, tülbent esaslı kumaşlar olup kesikli veya kesiksiz (filament) liflerden üretilir. Dokusuz yüzey, üretiminde 1sı ile birleştirme yönteminde taşıyıcı ve bağlayıcı lifler kullanılmaktadır. Ayrıca iki bileşenli lifler değişik oranlarda diğer liflerle karıștırılarak kullanılmaktadır. Bileşenlerin oranı kullanım alanına göre değişmektedir. İki bileşenli liflerin diş bölgesinde bulunan polimer madde düşük, iç bölgesinde bulunan polimer madde yüksek erime sıcaklığına sahiptir. Çalışma konusu olan hijyen tekstilinde, ADL tabakasında kullanılan ürünlerle ilgili yapılan çalışmalar incelendiğinde soya lifinin kullanıldığ çalışmaya rastlanmamıştır.

$\mathrm{Bu}$ çalışmada, hijyenik amaçlı kullanılan tekstil bazlı pedlerin, dağıtıcı tabakasında kullanılmak üzere; soya ve pamuk elyafinda dokusuz yüzeyler elde edilmiştir. $\mathrm{Bu}$ liflerin etkinliğini karşılaştırabilmek amacıyla mevcut halde hijyenik bebek ve hasta bezlerinin üretiminde zaten kullanılmakta olan konvansiyel dokusuz yüzey ADL ürünleri de üretilmiştir. Bu şekilde sekiz adet dokusuz yüzey kumaş numunesi üretilmiş ve kumaşlara bebek/hasta bezi için uygulanan performans testleri uygulanmıştır. $\mathrm{Bu}$ testler; kopma mukavemeti, kopma uzaması, sıvı geçişi, sslatma ve kuruluk testleridir. Test sonuçları bebek/hasta bezi ve hijyen tekstili açısından değerlendirilmiş ve yorumlanmıştır.

\section{MATERYAL VE METOT}

Bu çalışmada, materyal olarak, bebek bezi/hijyen tekstili amacıyla kullanılmak üzere dokusuz yüzey kumaşlar üretilmiştir. Bu kumaşlarda; taşıyıcı lif olarak soya ve pamuk, bağlayıcı lif olarak 6 Denye kalınlığında ve $64 \mathrm{~mm}$ uzunluğunda iki bileşenli iç/dış formunda PE (Polietilen)/PET(Poliester) ve iki bileşenli PE (Polietilen)/COPET (Modifiye edilmiş Poliester) elyafları kullanılarak doku birleştirme yapılmıştır. Soya ve Pamuk dokusuz yüzey numuneleri Air-Trough Bonding (Hava ile tülbent oluşturma) makinesinde $135^{\circ} \mathrm{C}$ 'de aşağıdaki proseslerde üretilmiştir.

\section{Elyaf Hazırlama $\rightarrow$ Kesikli Elyaf \\ 2. Doku Oluşumu $\rightarrow$ Kuru Serme Yöntemi $\rightarrow$ Taraklama serme (Çapraz Bağlama) \\ 3. Doku Birleştirme $\rightarrow$ Isıl Birleştirme}

Tülbent esaslı kumaşın üretiminde kullanılan iç/dış formundaki iki bileşenli lifler MERKAS A.Ş. (İstanbul/Türkiye) işletmesinden temin edilmiştir. İki bileşenli lifin iç/dış lif oranı 80/20'dir. Dış kısımdaki polimer madde (sheath) $110^{\circ} \mathrm{C}$ 'de erime noktasına sahiptir. İç kısımdaki (core) polimer madde $245{ }^{\circ} \mathrm{C}$ erime noktasina sahiptir. Isı ile bağlama aşamasında bu dış kısımda bulunan polimer madde eritilerek kompozit bir yap1 oluşturulmuştur. Araştırmada kullanılan dokusuz kumaş numuneleri ve içerikleri Çizelge 1'de verilmiştir. Burada $\mathrm{SO}$, soya lifini ve $\mathrm{CO}$ ise 
pamuk lifini ifade eder. PT, Polietilen/Polyester'i, CPT ise Polietilen/Modifiye edilmiş_polyester' $i$ ifade etmektedir. PT ve CPT karışım oranlarının farkına göre 1 ve 2 indislerini almışlardır (PT1, PT2, CPT1, CPT2).

Çizelge 1. Dokusuz yüzey üretiminde kullanılan numuneler ve içerikleri

\begin{tabular}{|l|l|l|}
\hline No & Numune Kodu & Numune İçeriği \\
\hline 1 & SO-PT1 & $\% 40$ SOYA $+\% 60$ PE/PET \\
\hline 2 & SO-PT2 & $\% 50$ SOYA $+\% 50$ PE/PET \\
\hline 3 & SO-CPT1 & $\% 40$ SOYA + $\% 60$ PE/COPET \\
\hline 4 & SO-CPT2 & $\% 50$ SOYA + $\% 50$ PE/COPET \\
\hline 5 & CO-PT1 & $\% 40$ PAMUK $+\% 60$ PE/PET \\
\hline 6 & CO-PT2 & $\% 50$ PAMUK + \%50 PE/PET \\
\hline 7 & CO-CPT1 & $\% 40$ PAMUK + \%60 PE/COPET \\
\hline 8 & CO-CPT2 & $\% 50$ PAMUK + $\% 50$ PE/COPET \\
\hline
\end{tabular}

Numunelere, Avrupa tülbent esaslı kumaş endüstrisini inceleyen EDANA kuruluşu standardına uygun olarak testler uygulanmıştır. Yapılan testler ve ilgili standartları Çizelge 2'de verilmiştir. Mukavemet testi; makine çeneleri arasına yerleştirilen numuneye söz konusu çeneler aracılığıyla kuvvet uygulanarak numunede kopma meydana getiren kuvvetin ve bu durumda numunede oluşan boyut değişiminin tespit edilmesi esasına dayanmaktadır. Her bir laboratuvar örneğinden, makine yönünden beş numune ve çapraz yönden beş numune test edilir. Sıvı geçişi test yöntemi; sıvı geçiş zamanını yani altına serilen bir standart emici ped ile temas halinde bulunan dokusuz yüzeyin bir test yüzeyine uygulanan belli bir hacimdeki sıvının (simüle idrar) dokusuz yüzeyden geçmesi için alınan zamanı ölçer. Her bir laboratuvar örneğinden 10 numuneyi taşınmasına direnme yeteneğini ölçer.
Standart bir emici ortam üzerine test eder. Islatma test yöntemi bebek bezi kumaşının, zaten kumaşa nüfuz eden bir sıvının deriye geri bir dokusuz yüzey yerleştirilir ve daha sonra belirli bir miktar simüle edilmiş idrar ile yüklenir. Sıvının yayılmasını sağlamak için dokusuz yüzey ve emici ortam üzerine standart bir ağırlık yerleştirilir. Daha sonra, önceden tartılmış bir toplama kağıt, dokusuz yüzey üzerine yerleştirilir ve ağırlık tekrar üste yerleştirilir. Emilen sıvının kütlesi toplama kağıdı ile tartılır. Her bir laboratuvar örneğinden 5 numuneyi test eder. Kuruluk test yöntemi; standart bir emici ortam üzerine konan ve dokusuz test numunesinin üzerine belirli bir test sıvısı kütlesi dökülüp eğimli bir düzlem üzerine yerleştirildiğinde, dokusuz bir test numunesinde akan test sıvısının (simüle edilmiş idrar) miktarını ölçme esasına dayanmaktadır.

Çizelge 2. Testler ve Standartları

\begin{tabular}{|l|l|}
\hline $\begin{array}{l}\text { Mest Adı } \\
\text { Mukine Yönünde Kopmati }\end{array}$ & Test Standardı \\
\hline $\begin{array}{l}\text { Çapraz Yönde Kopma } \\
\text { Mukavemeti }\end{array}$ & ERT 20.2-89 MD[N/5 cm] \\
\hline $\begin{array}{l}\text { Makine Yönünde Kopma } \\
\text { Uzaması }\end{array}$ & $\begin{array}{l}\text { ERT 20.2-89 MD } \\
\text { Elongation [\%] }\end{array}$ \\
\hline $\begin{array}{l}\text { Çapraz Yönde Kopma } \\
\text { Uzaması }\end{array}$ & $\begin{array}{l}\text { ERT 20.2-89 CD } \\
\text { Elongation [\%] }\end{array}$ \\
\hline $\begin{array}{l}\text { Makine Yönünde Islak } \\
\text { Kopma Mukavemeti }\end{array}$ & ERT 20.2-89 MD(WET) [N/5 cm] \\
\hline $\begin{array}{l}\text { Çapraz Yönde Islak Kopma } \\
\text { Mukavemeti }\end{array}$ & ERT 20.2-89 CD(WET) [N/5 cm] \\
\hline $\begin{array}{l}\text { Makine Yönünde Islak } \\
\text { Kopma Uzaması }\end{array}$ & $\begin{array}{l}\text { ERT 20.2-89 MD(WET) } \\
\text { Elongation [\%] }\end{array}$ \\
\hline $\begin{array}{l}\text { Çapraz Yönde Islak Kopma } \\
\text { Uzaması }\end{array}$ & $\begin{array}{l}\text { ERT 20.2-89 CD(WET) } \\
\text { Elongation [\%] }\end{array}$ \\
\hline Kuruluk & ERT 152.1-02 Run off [g] \\
\hline Sıvı Geçişi & $\begin{array}{l}\text { ERT 150.5-02 Strike } \\
\text { Through Time [sec] }\end{array}$ \\
\hline Islatma & ERT 151.3-02 Rewet [g] \\
\hline
\end{tabular}

\section{ARAŞTIRMA BULGULARI VE TARTIŞMA}

$\mathrm{Bu}$ bölümde Çizelge 2'de verilen test sonuçları karşılaştırılmıştır. Verilen grafiklerde dikey sütunda Çizelge 1'de verilen numunelere ait kodlar yer almıştır.

Şekil 3, Kopma mukavemetinin makine yönündeki test sonuçlarını göstermektedir. Burada, 
$\% 40$ SOYA + \%60 PE/COPET ve \%50 SOYA + $\% 50$ PE/COPET numunelerinde yüksek olduğu görülmektedir. COPET içeren pamuk numuneleri de olmasına rağmen soya içeriğinin makine yönündeki mukavemeti artırdığı söylenebilir. En düşük mukavemet, $\% 50$ PAMUK $+\% 50$ PE/COPET numunesinde görülmüştür.

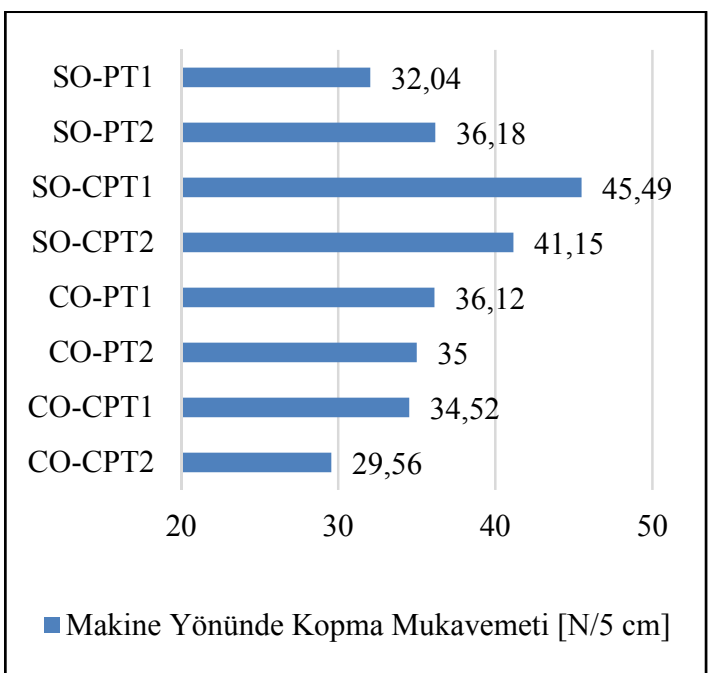

Şekil 3. Makine yönünde kopma mukavemeti test sonuçları

Şekil 4'te çapraz yöndeki kopma mukavemeti incelendiğinde \%50 SOYA + \%50 PE/COPET numunesinin enine yönde mukavemetinin en fazla olduğu görülmüştür. Enine yönde en düşük mukavemet, $\% 50$ PAMUK $+\% 50$ PE/PET numunesine aittir.

Şekil 3 ve 4'ten anlaşılacağı üzere Soya ve COPET içeren numuneler diğer numunelerden daha mukavemetlidir. Şekil 5 ve 6 ise numunelerin makine yönü ve çapraz yönü için kopma uzaması değerlerini göstermektedir.

Kopma uzaması, makine yönünde en fazla, \%40 PAMUK + \%60 PE/PET numunesinde olduğu (\%27.58) ancak mukavemette en yüksek değeri veren numune olan $\% 40$ SOYA + \%60 PE/COPET ile aralarında çok fark olmadığı (\%27.11) görülmektedir. Kopma uzamasında makine yönünde en düşük mukavemet, \%50 PAMUK + $\% 50$ PE/PET numunesinde görülmüştür.

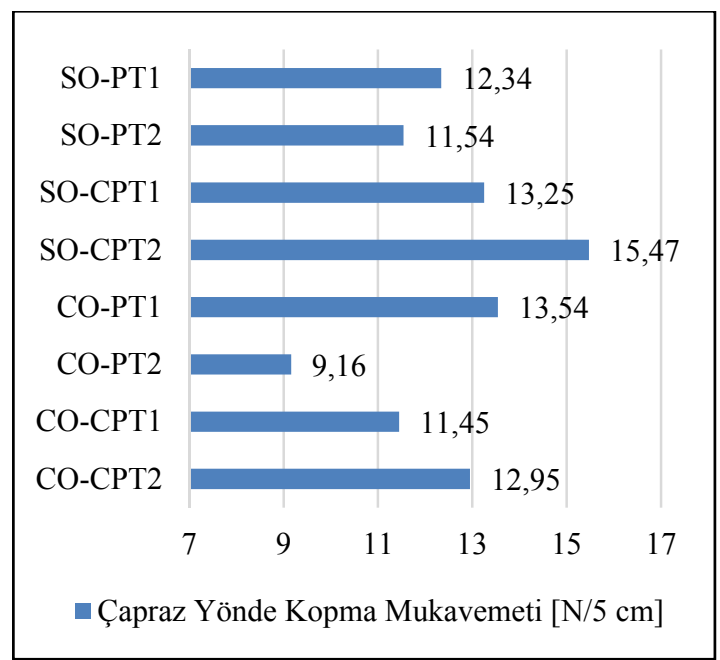

Şekil 4. Çapraz yönde kopma mukavemeti test sonuçları

Kopma uzamasının çapraz yönde test sonuçlarında ise $\% 40$ SOYA + \%60 PE/COPET daha iyi sonuç vermiştir $(\% 36,45)$. Çapraz yönde en düşük kopma uzaması değeri, \%50 SOYA + \%50 PE/PET numunesine aittir.

Şekil 5 ve 6'dan anlaşılacağı üzere, genel olarak $\% 40$ SOYA + \%60 PE/COPET numunesi diğer numunelere göre daha iyi kopma uzamasina sahiptir.

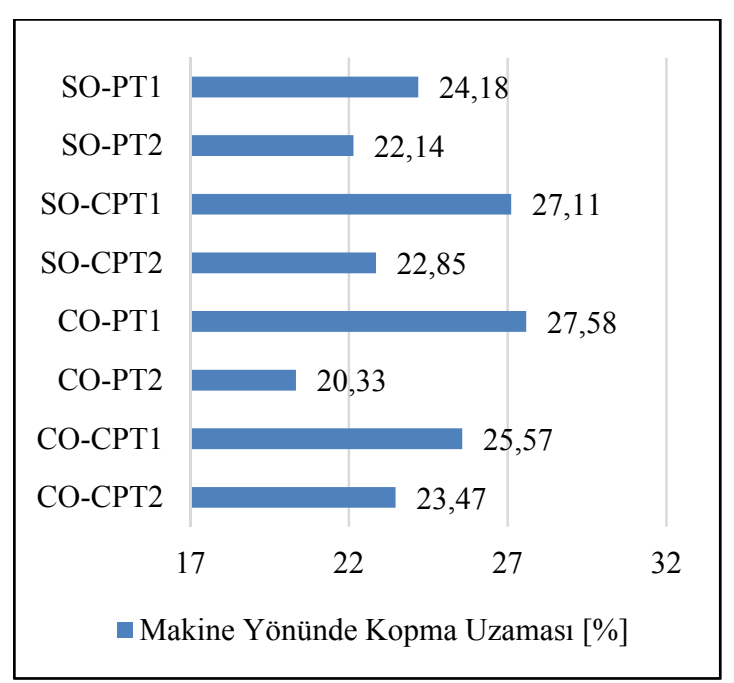

Şekil 5. Makine yönünde kopma uzaması test sonuçları 


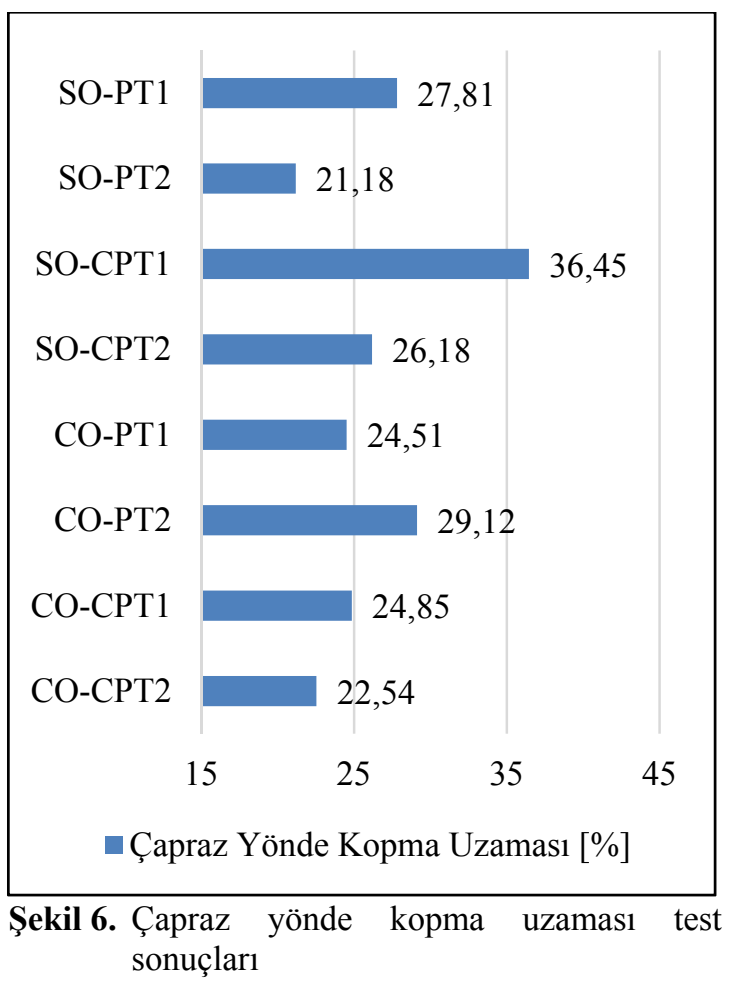

Numuneler bebek bezi ve hijyen tekstiline yönelik hazırlandığı için sslak mukavemetinin de değerlendirilmesi önem arzetmektedir. Şekil 7 ve 8 incelendiğinde numunelerin makine yönü ve çapraz yönü islak kopma mukavemeti değerleri verilmiştir.

Islak kopma mukavemeti makine yönünde en yüksek $\% 40$ SOYA $+\% 60$ PE/COPET numunesinde görülürken en düşük islak kopma mukavemeti $\% 50$ PAMUK + \%50 PE/COPET numunesinde görülmüştür.

Islak kopma mukavemeti çapraz yönde en yüksek test sonucu $\% 50$ SOYA $+\% 50$ PE/COPET numunesinde olduğu, en düşük islak kopma mukavemeti ise \%50 PAMUK + \%50 PE/PET numunesinde olduğu görülmüştür.

Şekil 7 ve 8 'den anlaşılacağı üzere sslak kopma mukavemeti test sonuçlarında Soya ve COPET içeren numune en yüksek değere sahipken iki testte de en düşük değerin Pamuk içeren numunelerde olduğu görülmüştür.

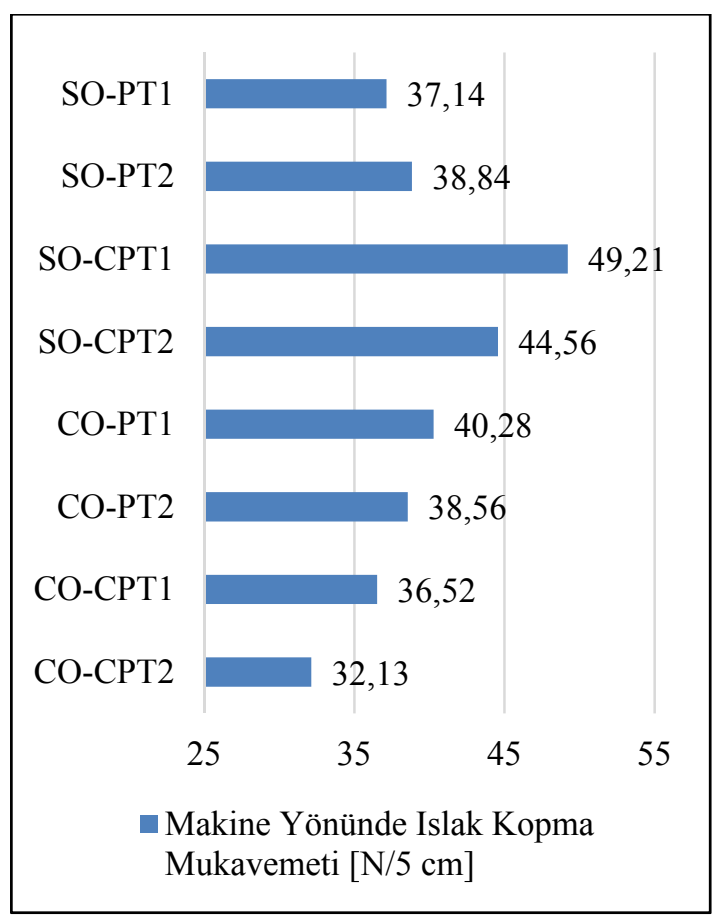

Şekil 7. Makine yönünde 1slak kopma mukavemeti test sonuçları

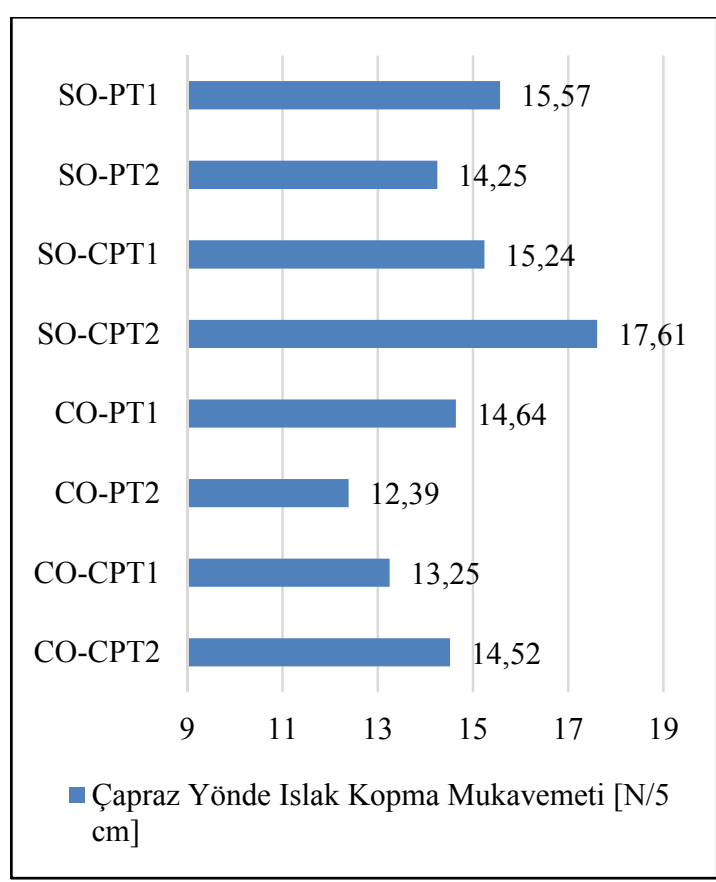

Şekil 8. Çapraz yönde islak kopma mukavemeti test sonuçları 
Sekil 9 ve 10 incelendiğinde numunelere ait makine yönü ve çapraz yönde islak kopma uzaması test sonuçları görülmektedir. Makine yönünde sslak kopma uzaması test sonucuna göre en yüksek değerin \%40 SOYA + \%60 PE/COPET numunesine, en düşük değerin ise \%50 PAMUK + $\% 50$ PE/PET numunesine ait olduğu tespit edilmiştir. Çapraz yönde de islak kopma uzaması test sonucuna göre en yüksek değerin yine $\% 40$ SOYA + \%60 PE/COPET numunesine, en düşük değerin ise $\% 50$ PAMUK $+\% 50$ PE/COPET numunesine ait olduğu tespit edilmiştir.

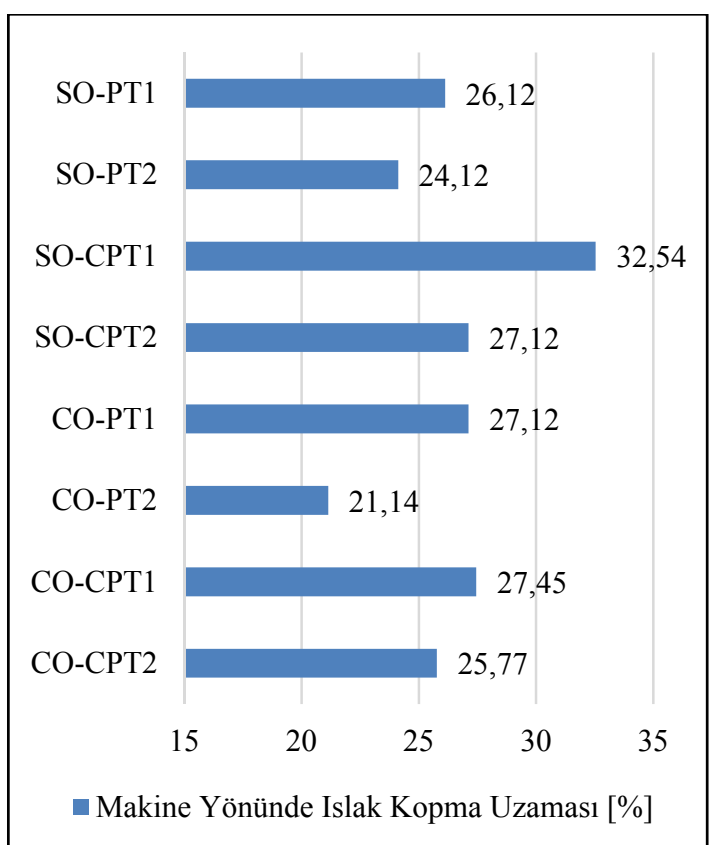

Şekil 9. Makine yönünde rslak kopma uzaması test sonuçları

Şekil 9 ve 10'dan anlaşılacağı üzere soya ve COPET karışımlı numunenin en yüksek 1slak kopma uzamasına sahip olurken Pamuk -PET ve Pamuk COPET karışımlı numunelerinin en düşük değerlere sahip olduğu görülmektedir.

Bebek bezinin temel fonksiyonu, bebeğin idrar ve dışkısını dışa taşırmadan hızlı emip geri 1slatmayarak kuru bir yüzey sağlamasıdır. Çocuk bezi için sıvı geçiş hızı testi, ıslatma testi ve kuruluk testi büyük önem taşımaktadır. Bu nedenle sıvı geçiş hızı düşük olan değer tercih edilir.

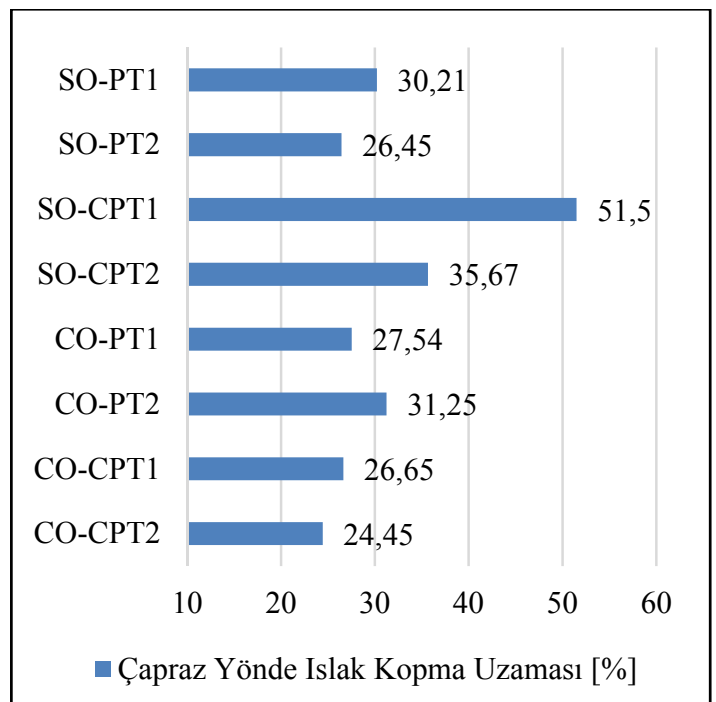

Şekil 10. Çapraz yönde 1slak kopma uzaması test sonuçları

Şekil 11'de numunelere uygulanan sıvı geçiş hızı test sonucu incelendiğinde $\% 50$ SOYA $+\% 50$ $\mathrm{PE} / \mathrm{PET}$ numunesinin (SO-PT2) en kisa sürede siv1 geçişi sağladığını, aralarında az bir fark $(0,02)$ bulunan $\% 40$ SOYA + \%60 PE/COPET $(1,61$ sn $)$ ve $\% 40$ PAMUK $+\% 60$ PE/COPET (1,63 sn) numunelerinin diğer numunelere göre daha uzun sürede sıvı geçişi olduğu görülmektedir. İki numunede ortak özelliğin COPET olması nedeniyle bu materyalin kuru kalmada olumsuz etki (1slak hissetme) yaptığı söylenebilir.

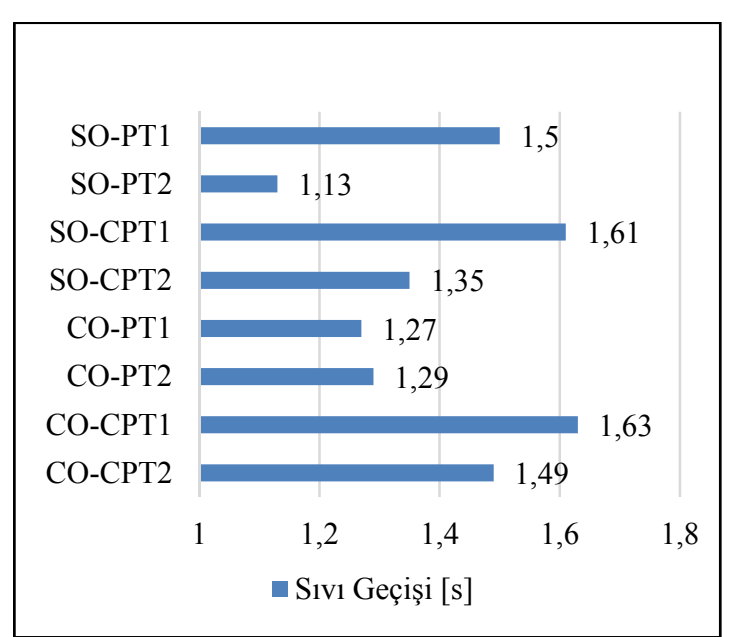

Şekil 11. Sıvı geçiş hızı test sonuçları 
Sekil 12'de numunelerin islatma test sonuçarı verilmiştir. $\mathrm{Bu}$ testte, kumaşa nüfuz eden bir sıvının deriyi geri taşınmasına direnme yeteneği ölçülmektedir. İncelendiğinde numuneler arasında çok fazla bir fark olmamakla beraber en yüksek Sıv1 ağırlığının \%50 SOYA + \%50 PE/COPET numunesine ait olduğu sonucuna varılabilir. Soya lifi içeren numunelerin tamamının 1slatma sonuçları kabul edilebilir değerlerde çıkmıştır. $\mathrm{Bu}$ durumda bünyesine aldığı sıvının geri iletildiği miktarı tespit eden bu testte olumlu sonuçlar elde edildiği söylenebilmektedir.

Kuruluk testi, standart bir emici ortam üzerine konan ve dokusuz test numunesinin üzerine belirli bir test sıvısı kütlesinin dökülmesi, eğimli bir düzlem üzerine yerleştirilmesi ve test numunesinden akan sıvının ölçülmesini ifade eden bir testtir. $\mathrm{Bu}$ test yapıldığında ise tüm numunelerde değerin sıfır olduğu tespit edilmiştir. Bebek bezi için kuruluk ifade eden bu testte soya lifi içeren numunelerin uygun olduğu görülmektedir.

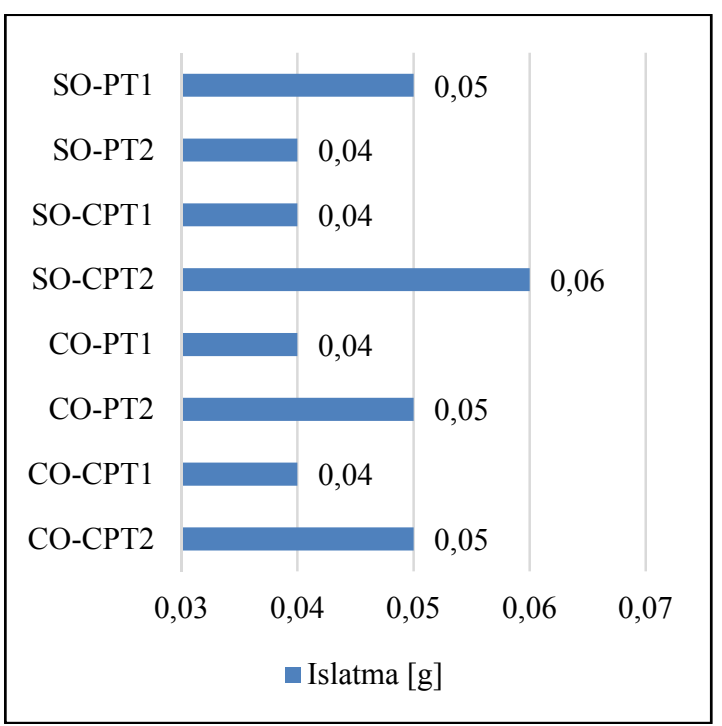

Şekil 12. Islatma test sonuçları

\section{SONUÇ}

$\mathrm{Bu}$ çalışmada soya lifinin bebek bezi ve ayrıca hijyenik tekstil yüzeyi üretiminde kullanılabilirliği araştırılmıştır. Elde edilen dokusuz yüzey tekstil ürünlerinin dikkat çeken sonuçları aşağıda özetlenmiştir:

- Makine yönü mukavemet testlerinde, kuru numunede en iyi sonuçlar pamuk/polietilen/ modifiye_polyester'den, sslak numunelerde ise soya/polietilen/modifiye_polyester'den elde edilmiştir.

- Soya içeren numuneler sslak halde daha mukavemetli olduğu görülmüştür.

- Çapraz yönde mukavemet sonuçlarında ise en iyi değerler; kuru ve rslak halde soya/ polietilen/modifiye_polyester numunelerinden elde edilmiştir. Soyanın varlığı bebek bezinin kopma mukavemetinde olumsuz bir özellik vermediği gibi mukavemeti artırıcı bir etki yapmıştır.

- Mukavemet açısından en kötü sonuçlar, makine yönü kuru ve rslak hale pamuk/polietilen/ modifiye polyester'den, enine yönde kuru ve sslak hale pamuk/polietilen/polyester numunelerinde elde edilmiştir.

- Sıvı geçiş hızı, ıslatma ve kuruluk değerlerinde de Soya/polietilen/polyester numuneleri en iyi sonucu göstermiştir.

- Bebek bezi performansında konfor anlamında önemli olan bu son üç testte de, mukavemette olduğu gibi, soya lifinin oldukça iyi değerlere sahip olduğu görülmüştür.

Sonuç olarak; antibakteriyel, biyobozunur ve yenilenebilir bir lif olan soya lifinin günlük yaşamda oldukça fazla tüketimi yapılan bebek bezi/hijyen tekstili ürünü olarak da kullanılabileceği bu çalışma ile ortaya konulmuştur.

\section{TEŞEKKÜR}

$\mathrm{Bu}$ çalışma, Çukurova Üniversitesi Bilimsel Araştırma Projeleri Koordinasyon Birimince Yüksek Lisans Proje türünde desteklenmiş (Proje kodu: FYL-2015-5315) olup teşekkürü borç biliriz. 


\section{KAYNAKLAR}

1. Yıldırım, F.F., Avinç, O.O., Yavaş, A., 2014. Soya Fasulyesi Protein Lifleri Bölüm 1, Uludağ Üniversitesi Mühendislik Fakültesi Dergisi, 19(2), 29-50.

2. Yıldırım, F.F., Avinç, O.O., Yavaş, A., 2015. Soya Fasulyesi Protein Lifleri Bölüm 2, Uludağ Üniversitesi Mühendislik Fakültesi Dergisi, 20(1), 1-21.

3. Yılmaz, D., Karaboyacı, M., Kılıç, H., Kitapçı, K., Yelkovan, S. 2015. Comparison of Selected Properties of Eco-Friendly Soybean and Other Fibres. Fibres \& Textiles in Eastern Europe 23, 3(111), 14-24.

4. Özgen, B., Altaş, S., 2014. Farklı Liflerden Üretilmiş Örme Kumaşların Isıl Konfor, Nem İletimi ve Tutum Özelliklerinin İncelenmesi, Tekstil ve Konfeksiyon, 24(3), 272-278.

5. Wu, H.Y., Zhang, W.Y., Li, J., 2009. Study on Improving the Thermal-Wet Comfort of Clothing during Exercise with an Assembly of Fabrics. Fibres \& Textiles in Eastern Europe, 17, 4(75), 46-51.

6. Avc1, H., 2007. Yeni Liflerden Mamul Çorapların Konfor Özellikleri, Yüksek Lisans Tezi, İstanbul Teknik Üniversitesi, Fen Bilimleri Enstitüsü, 81.

7. Jia, Z., Yang, Y., 2007. Surface Modification of Polyacrylonitrile (PAN) Fibers by Grafting of Natural Polymer-soybean Protein (SP), Polymer Bulletin, 59, 13-23.

8. Üçgül, İ., Saral, E., Avcı, Y., 2013. Tek Kullanımlık Bebek Bezi Tüketiminin Çevresel Incelenmesi, Tekstil Teknolojileri Elektronik Dergisi, 7(1), 1-5.

9. Bartels, V.T., 2011. Handbook of Medical Textiles, Woodhead Publishing Series in Textiles Number 100, The Textile Institute.

10. https:/www.catsis.com.tr/merkas-tekstil-as (Erişim Tarihi, Mayıs 2018). 